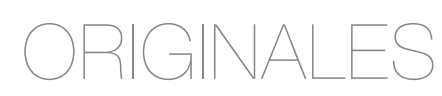

\title{
Analysis of "The Small Farmer" by Gastón Acurio: A case of poverty romance in organic discourse
}

DANIEL SALAS* 
COMO CITAR ESTE ARTÍCULO

How to cite this article:

Salas, D. (2020). Analysis of "The Small Farmer" by Gastón Acurio: A case of poverty romance in organic discourse. Revista Perspectiva Empresarial, 7(2), 24-35.

Recibido: 16 de julio de 2020

Aceptado: 03 de octubre de 2020
ABSTRACT This study will analyze a brief text by Peruvian chef Gastón Acurio, leader of the so-called Peruvian gastronomic boom, in order to explain how he develops a discursive strategy aimed at generating resistance to technological changes, especially in the field of transgenic foods. This analysis becomes necessary given that digital social networks have become very influential spaces for the formation of opinion. At the same time, Gastón Acurio is not only an influential businessperson but also one of those new media characters that we call "influencers" and that have thousands of followers.

His text is part of a campaign against the use of genetically modified organisms -GMOs-in Peru. Acurio's textual strategy was creating a fictional character; a small farmer living in a poor but bucolic world, far away from the greedy needs of the city, happy with his modest life, and in no need for riches.

KEYWORDS Information and communication, agriculture, storytelling, critical discourse analysis, corporate social responsibility, ethics.

\section{Análisis de "El pequeño agricultor" de Gastón Acurio: un caso de romance de la pobreza en el discurso orgánico}

RESUMEN En este estudio se analizará un breve texto del chef peruano Gastón Acurio, líder del llamad o boom gastronómico peruano, para explicar cómo desarrolla una estrategia discursiva destinada a generar resistencia a los cambios tecnológicos especialmente en el campo de los alimentos transgénicos. Este análisis se hace necesario dado que las redes sociales digitales se han convertido en espacios muy influyentes para la formación de opinión. Al mismo tiempo Acurio no solo es un empresario influyente, sino también uno de esos nuevos personajes mediáticos que llamamos "influencers" y que tienen miles de seguidores.

Su texto forma parte de una campaña contra el uso de organismos genéticamente modificados -OGM - en Perú. La estrategia textual de Acurio fue crear un personaje de ficción; un pequeño agricultor que vive en un mundo pobre, pero bucólico, alejado de las necesidades codiciosas de la ciudad, feliz con su modesta vida y sin necesidad de riquezas.

PALABRAS CLAVE información y comunicación, agricultura, narración, análisis crítico del discurso, responsabilidad social empresarial, ética. 


\section{Análise de “0 pequeno agricultor” de Gastón Acurio: um caso de romance de pobreza no discurso orgánico}

RESUMO Neste estudo, será analisado um breve texto do chef peruano Gastón Acurio, líder do chamado boom gastronômico peruano, para explicar como ele desenvolve uma estratégia discursiva que visa gerar resistência às mudanças tecnológicas, especialmente no campo dos alimentos transgênicos. Essa análise se faz necessária tendo em vista que as redes sociais digitais se tornaram espaços de grande influência para a formação de opinião. Ao mesmo tempo, Acurio não é apenas um empresário influente, mas também um daqueles personagens da nova mídia que chamamos de “influenciadores” e que têm milhares de seguidores.

Seu texto faz parte de uma campanha contra o uso de organismos geneticamente modificados - OGM - no Peru. A estratégia textual de Acurio era criar um personagem fictício; um pequeno agricultor que vive em um mundo pobre, mas bucólico, longe das necessidades gananciosas da cidade, feliz com sua vida modesta e sem a necessidade de riquezas.

PALAVRAS-CHAVE informação e comunicação, agricultura, contação de histórias, análise crítica do discurso, responsabilidade social corporativa, ética. 


\section{Genetic Modification from a Scientific Perspective}

In recent decades, especially since 1980 , food engineering has made great strides in providing better and more efficient seeds to farmers in various parts of the world. GMOs contain genes taken from other species in order to improve some of its traits, for example, resistance to pests and pesticides, improvement of its nutritional capacities, less need for water and soils. Any species that has obtained genes from any other species is transgenic, also known as GMOs (Krebs, Goldstein and Kilpatrick, 2014). However, in popular culture GMOs are associated with the unnatural, anti-ecological, toxic and alien. Yet, all those claims are unscientific. For example, there are natural GMOs, not developed in laboratories but which are the product of evolution; GMOs are also more effective as ecological products since they reduce the use of pesticides, water and soil. In 2019, Uruguay, producer of transgenic soybeans, saved 500000 hectares of land thanks to this technology. Economic benefits to farmers and significant reduction of pesticides coupled with increased production are also well documented. Data on GMO corn in the U.S. strongly support this conclusion (Taxler, 2006; Klümper and Qaim, 2014; Benbrook, 2012). Products essential to human health today, such as "human insulin" are the result of this type of technology.

On the other hand, GMOs are just one of the techniques of genetic transformation. The most traditional one that humanity has had for at least ten thousand years is the artificial selection of the best seeds and hybridization. Finally, after the advancement of transgenic technology, CRISPR, a much more advanced form of modification that consists of working with the genes of specimens in order to mitigate or increase their effects, was developed. CRISPR technology so far has been introduced in agriculture and farming and even for the cure of genetic diseases (Ormond et al., 2017; Gupta and Musunuru, 2014; Hsu, Lander and Zhang, 2014; Komor, Badran and Liu, 2017; Lander, 2016).

In fact, according to biologists, the possibilities opened up by applied genetic research are enormous for the remediation of ailments that used to have be treated with drugs and surgeries with undesirable side effects. Due to the abundance of misinformation in this regard, some researchers argued about the need to develop "socio-education" as a way of connecting scientists and technologists with the public (Solli, Bach and Akerman, 2014).

However, the fear of this new technology is deeply rooted in the world and spreads thanks to dubious and extremely cautious reports but above all, to the sources of fake news information. The main motive for these accounts is a conspiracy theory inspired by the old fear that man would seek to replace God-created nature.

This is the great theme of Mary Shelly's Frankenstein science fiction, which originally pretended to be a horror story. Although it cannot be argued that this modern fear is due to the reading of this novel, there is no doubt that Shelly's novel contributed to reflect (from a romantic perspective in which science rose with splendor) the not so much technical but moral limits of human knowledge. In our times, the question whether the human being has the power or the right to correct the divine work is transformed into an atheistic version of popular ecology. Nature are portrayed as based on harmony whilst human civilization creates an imbalance that can be irreversible and dehumanize us, to the point that Nature will turn against ourselves, in a sort of cosmic rebellion.

Unfortunately, scientific arguments are difficult to turn into propaganda because they require complex arguments and do not dare to offer categorical answers. Jamieson (2017) explained the difficulty of science in communicating its results due to the intrinsic traps of language that reside in the prevalence of commonplace and, above all, to the caution inherent in scientific language for which, for example, the expression "safe to eat" is not acceptable. From a scientific point of view, there is no such thing as a technology that is completely "safe." As Lakatos (1978) argued, unlike propaganda and even Popperian epistemology, science is probabilistic. Since the evidence for the safety of GMOs and their benefits to the environment and farmers is overwhelming (Saik, 2019), concerns about its iniquity are unfounded.

Having pointed this out, this paper admits a highly accurate scientific conclusion, namely, that climate change is occurring and is highly likely that 


\section{Moratorium on GMOs in Peru}

The success of the anti-transgenic campaign in Peru is evidenced by the fact that, despite the overwhelming scientific evidence in favor of the use of genetic modification, the organic and antitransgenic discourse is not only extremely popular but has much influence on Peruvian governments. In Peru, efforts of President Alan García during his second (2001-2006) right-wing mandate to allow the use were they frustrated by the election of leftleaning President Ollanta Humala. According to Dargent and Urteaga (2019), the fact that its use came too late made the political pro-GM lobbying ineffective. On the other hand, in the governments of the Latin American region where its use was previously there was no time for both national and international resistance groups to articulate.

With the support of a new parliamentary majority and a national anti-GM consensus, the President Ollanta Humala signed Law 29881 in November 2012, which imposed a ten-year moratorium on GM technology in Peru. As part of the moratorium, a the Ministry of Environment ordered a report that was published in 2016 and aimed to make a foresight about the effects of modified seeds for Peruvian crops and the economy of producers.

President Humala's decision, which reversed García's, was strongly driven by chef Gastón Acurio, whose fame and prestige has allowed him to generate a strong current of opinion in which he has involved a large part of consumers and the industry itself, many of whom seek "organic" certification to give greater value to their products.

\section{Narrative persuasion and organic foods}

From Labov's (1982) breakthrough work, the idea has developed that the construction of common human knowledge possesses a narrative form. Bruner (1991) is one of the best-known researchers for this current of thought that has been extremely helpful in understanding fiction not as a peculiar aspect of cognition but rather as a central element through which we construct possible worlds. In his very influential essay, Bruner (1991) explained that the empiricist or rationalist model of the development of knowledge presupposes a kind of "scientific child" who submits hypotheses to verification and in this way progressively develops his ideas. Bruner, on the other hand, proposed that the human being constructs his knowledge in the form of narratives that have the purpose of constructing meaning. Human beings tend to seek the meaning of the world and their own subjectivity, not necessarily truth. The search for meaning is possible in light of narration, whose basic element is time. The organic and anti GMOs discourse fulfills this characteristic.

Such duality, however, is purely a construction of discourse. Because, in fact, there is no evidence that organic or transgenic products possess the characteristics indicated.

Of special interest is the "natural" trait attributed to organic products that allows us to observe how the idea of "natural" is actually a conceptual construction. Organic products are the result of both contemporary techniques and thousands of years of artificial selection that have allowed the domestication of the fruits we consume today. The food market is composed mainly of fruits or animals domesticated by resorting to the selection of farmers and stockbreeders. The exception consists of a minority of wild fruits or animals, such as products obtained by hunting or fishing. The industrialization of livestock, 
agriculture and fish farming has enabled the world's population to access quality food at low prices. However, even products considered more "natural" such as broccoli, potatoes or fruits are the result of selection and hybridization processes. Biotechnology nothing but a new chapter in the task of domestication of the species of animals and plants that serve human consumption.

This long and complex history of this process of dominating the species that serve as food are narrated in a way that hides its artificiality and presents it as a natural process as long as it is affirmed that it does not violently break into biological processes. This representation is a way of giving the "natural" product, and especially the one labelled as "organic," the value of being in harmony with nature.

This organic labelling is strongly connected with the construction of social capital, studied in depth by Bourdieu $(1985,1986,1989)$. "Healthy foods" and in particular "organic food" have already become signs of distinction as the access and ostentation of their consumption gives the consumer a membership in an exclusive group. As Bourdieu pointed out (1985), the reproduction of social capital presupposes an incessant effort of sociability, a continuous series of exchanges in which recognition is interminably affirmed and reaffirmed. Properly, famines have ceased to be a problem for humanity. Instead, the quality of the food is at stake. The upper classes today point to their social status through ostentatious yet "healthy" ways of eating that reinforce the networks of relationships. "The Small Farmer" is a story that justifies this distinction, using an archaic and idyllic vision of the origin of food.

\section{The Small Farmer}

Acurio'stext is been chosen by be agood epitome of the type of narrative used against biotechnology. The following is a complete transcription of the text that is the subject of our analysis:

But why would I want to trade my corn farm for yellow corn just because it will give me more profits? What does profit mean, money? Allow me to explain, dear friend.
For me and my family, this corn plant is pride, a treasure and a legacy from my grandparents whoin turn received it from their grandparents hundreds of years ago. It's a family legacy and that has a very important value for us.

This plant also grows in this land long before us. She is the daughter of this land. Land is a system in which corn, insects, herbs, everything has a harmony achieved with patience and years. If I take her corn, if I take her son and bring him a rare corn, the earth will be very upset. Maybe you don't understand me, but for us, the land, the Pacha Mama [mother land] is the most valuable thing we have. We don't want to disturb her.

This corn is also a plant whose leaves serve as food for our pets. The same ones that make my children happy every day, the ones that bring us joy and bring out the best in our feelings by stroking them. These leaves are the only thing they have always ate. If I take away their food, and give them another, they would cease to be happy and would make us very unhappy. This has a great value.

This corn also has stems that my children play from small to suck their sugar. It's their candy and they're happy with it. If I take them off, the'll lose their smile, and this is the most valuable thing we have.

With this corn, we also make all the recipes that we have loved so much since all our lives, our humitas [fresh corn tamales], our corn with cheese, our lawita [corn soup]. What would we do with that other corn? This is of immense value.

And finally, we sell the rest of the corn at a price that each day is fairer because, I do not know if you know dear friend: Every day, people want more and more our choclito while yours, I have been told, every day they want less.

Dear friend, it seems that there in the city the value is only money. Of course we would like to earn more money but much more important for us is to gain moments of happiness, respect and appreciation for our history and our land.

What would I do with the extra money you make on your yellow corn? Well, I would run to the market to buy corn, leaves, stems, so that my children can laugh, my pets can be happy, so our days have the same flavor, to desperately recover our life. 
Thank you my friend, as you will see, we keep our corn for many reasons but above all because its value is our life, and that is much greater than money.

\section{Analysis}

\section{A strong dichotomy}

Organic labeling is strongly connected with the construction of social capital, studied in depth by Bourdieu (1985, 1986, 1989). "Healthy food" and in particular "organic food" have already become signs of distinction, while access and ostentation of its consumption grant the consumer a membership to an exclusive group. As Bourdieu (1985) pointed out, the reproduction of social capital presupposes an incessant effort of sociability, a continuous series of exchanges in which recognition is endlessly affirmed and reaffirmed. Properly, famines have ceased to be a problem for humanity and cheap food is almost accessible to the poorest. Therefore, it is the quality of the food, not the abundance, what signalizes status. The upper classes today indicate their social capital through ostentatious and at the same time "healthy" ways of eating that reinforce the networks of relationships. "The Small Farmer" justifies this distinction, using an archaic and idyllic vision of the origin of food and appealing to the poorest member of the production chain. The least favored by organic industry is happy to be part of the chain and the guardian of the authenticity of the product and the fairness of the trade.

By championing the vision of fair trade and the idea of "authenticity," Acurio has succeeded in installing a strong dichotomy in consumer's mindset, especially the wealthy one who can afford these products. That is, the dichotomy between organic and GMOs products. The first being ecological, healthy and tasty ingredients, the second being polluting, unhealthy and disgusting. If Mother Nature has provided us of healthy, delicious and natural products, humans must not challenge its perfection. Consumers must prefer "organic" and "native" products not because they actualize social capital but because they offer positive features, as opposed to negative features of technological foods.
Table 1 summarizes the dichotomy that structures the literary distinction between organic and GMOs foods:

Table 1. The Literary Dychotomy of Organic vs. GMOs

\begin{tabular}{ll}
\hline \multicolumn{1}{c}{ Organic } & \multicolumn{1}{c}{ GMOs } \\
\hline Ecological & Polluting \\
\hline Healthy & Unhealthy, toxic \\
\hline Pure & Impure \\
\hline Natural & "Frankenfoods” \\
\hline Tasty & Disgusting \\
\hline Authentic & Alien \\
\hline Ethical & Unethical \\
Spiritual & Materialist \\
\hline
\end{tabular}

Source: author own elaboration.

\section{Chronotope}

"The Small Farmer" resorts as a basic tool to what Bahktin (1982) called "chronotope," which he applied especially to his analysis of novels. In this case, the chronotope is that of the countryside and the labor of the poor peasant. It is characterized by its austerity and to sustain a circular vision of time, which harmonizes with nature, expressed in the growth of the crop. In the chronotope used, there is harmony between time, nature and the cycle of sowing and harvest. Being a cyclic time, it does not admit the change or, if it appears, it will be in the form of a disturbance.

Since change necessarily implies decadence or progress, the temporary setting of the story is a motionless.

\section{Genre}

Acurio's tale romanticizes peasants' life and labor by recurring to the bucolic genre. The country is a pastoral fantasy in which individuals experiencing the alienations of the postmodern, postindustrial, societies can travel on time and grasp the experience of an imaginary origin of humanity. In that imaginary past, nature harmonizes perfectly and deeply with human labor: "For me and my family, this corn plant is pride, a treasure and a legacy from my grandparents who in turn received it from their grandparents hundreds of years ago. 
It's a family legacy and that has a very important value for us."

Thus, eating organic and "natural" foods is not only a physiological satisfaction but also a spiritual one. This textual strategy masks the symbolic capital that the consumption of organic products implies.

The countryside is dominated by beauty and harmony. The city by the stress, uncertainty and trade. Within the analyzed text, the small farmer means "the poor farmer," opposed to the large farmer or the agro-industrial. The first values the austere life and the certainty that must be passed on in a pure way to the next generation (the children). The small farmer is not represented as a trader, because he does not sell products; he is not interested in transforming his production into another good. His corns are ends in themselves that give joy to those who acquire them and to himself. As the text says: “Maybe you don't understand me, but for us, the land, the Pacha Mama [mother land] is the most valuable thing we have. We don't want to disturb her." The sentence "Maybe you don't understand me" situates the second person in a possible axiological locus. "You" may not understand the farmer because your values are different, that is, "you" value profit whilst the farmer values tradition and a life or harmony with the land. The value of the "Pacha Mama" is not to be calculated in monetary terms. Offering profits to the small farmer is insulting.

\section{Fetishism}

The story also has a strong fetishist element. According to Westropp (1880), fetishism is "a belief that a spirit is considered as embodied in certain material objects, as a stalck or stone, and that such objects are treated as having consciousness and power, and are to be worshipped, prayed to, and sacrificed to" (p. 304). In Acurio's story, earth is a living being that can love or be angry. Technology, greed and GMOs are monsters that violate her and will make her annoyed: "If I take her corn, if I take her son and bring him a rare corn, the earth will be very upset."

This fetishist feature links Acurio's story with bucolic tales, framed within an environment of beauty and purity threatened by monsters that are invariably ugly and evil. The bucolic tale does not admit mediocrity: Either the stage or the character is good and beautiful or it is malignant and ugly. Neither in does Acurio's text foreign elements are impure and corrupt the harmonic relationship between farmer and nature: "Land is a system in which corn, insects, herbs, everything has a harmony achieved with patience and years."

There is an interesting contradiction in the text. On the one hand, the corn is the result of their hard work but at the same time is a fruit given away by the land. The land renders its fruits to the farmer on the condition that he treats it well. It is see as a mother who provides for her children to the extent that her children protect her. As you can see, the motive of mutual care is crucial for the maintenance of the story and forms the following association: Earth - mother - child - mutual protection. The peasant then has a filial, familiar relationship with the land. He does not consider it "his" in the sense that it is property. It is "yours" as can be yours, your mother or your family. The implicit contract is that the land will give beautiful and tasty corn, as long as it is respected.

\section{Hiding the contradictions}

A very important resource for propaganda stories is to hide contradictions and avoid any problematization. To be convincing, you must divide history between the beautiful and the good and the ugly and the bad. The text addresses the second person by establishing a frontier between the country and the city. The city is a place of greed in which money has more value than spiritual experiences: "Dear friend, it seems that there in the city the value is only money. Of course we would like to earn more money but much more important for us is to gain moments of happiness, respect and appreciation for our history and our land."

A perfect status quo has been stablished by a millenary tradition and it is not to be questioned without suffering a backlash from Mother Nature and the anger of the ancestors: "If I take her corn, if I take her son and bring him a rare corn, the earth will be very upset." New technology may be more profitable but searching for money is a greed, which is in conflict with the generosity of Mother Nature. The small farmer is not interested in money because neither he nor his family need it. They live in the past, in a self-satisfactory world untouched by the sin of 
greed. The small farmer does not sell his products. He gives us them away. He is generous because Mother Nature ("Pachamama") is generous to him.

In the following table, the elements that distinguish the countryside and the city are unpacked and the strong congruence in this separation is observed. The reader should not notice that he or she lives in the city. However, you must come to believe that country life is enviable and good. Table 2 summarizes the distinction between the country and the city according to this narrative:

Table 2. The Literary Dychotomy of the Country and the City

\begin{tabular}{ll}
\hline \multicolumn{1}{c}{ Country } & City \\
\hline Natural & Artificial \\
\hline Animated & Alienated \\
Idyllic & Materialistic \\
Focused on happiness & Focused on economic success \\
In harmony with the past & In conflict with the past \\
\hline Qualitative focus & Quantitative focus \\
\hline
\end{tabular}

Source: author own elaboration.

Can he or she resolve this contradiction, that is, that he or she consumes a product of the countryside in the city? The way to achieve this is through the fantasy of consumption reinforced by fiction. This beautiful, delicious and organic corn allows the city's consumer to have access to a piece of pure land that does not exist in the alienated life of the city. A fundamental principle of fantasy is that the subject dreams or desires what he does not have. The king dreams of being a beggar or having an anonymous life without the demands of power. The beggar dreams of being a king and having the wealth and power of the one he lacks.

Modern advertising follows that principle. It does not seek to resolve the contradiction but to hide it. The consumption of that beautiful, pure and organic corn, product of mother earth and not of the work of the farmer or contaminated by technology, becomes a fantasy way to evade, even for a moment, the impure, alienating, capitalist and technological life of the city. In other words, it offers us comfort and a way to live a dream.

Above all, and this is the most interesting thing, it justifies and comforts us by the life of extreme poverty of the "small farmer" who is happy, not despite but precisely because of his austere life and without material aspirations: "Dear friend, it seems that there in the city the value is only money. Of course we would like to earn more money but much more important for us is to gain moments of happiness, respect and appreciation for our history and our land." He lacks greed, ambition, a desire to change reality because that would be to violate the earth and history. In this text, "history" has a cyclic meaning.

The peasant offers us the inheritance of his history but it is not a history of conflicts between social classes nor a rigorous struggle for survival but of ancient harmony with nature and the gods. In other words, Acurio's text is based on a vision of Arcadia that has reached modernity not through classical literature but through cinema and oral traditions. Therefore, even if the readers do not know and even if the author of the text is unaware of it, in this text are present motifs inherited from classical tradition and the Spanish Baroque such as the locus amoenus and the contempt of court and praise of village that are typical of pastoral stories: "What would I do with the extra money you make on your yellow corn? Well, I would run to the market to buy corn, leaves, stems, so that my children can laugh, my pets can be happy, so our days have the same flavor, to desperately recover our life." 
The famous scene from Antoine de SaintExupery's The Little Prince, in which the main character is offered thirst-quenching pills that would save him time, inspires the previous paragraph. The Little Prince replies that if he had more time available, he would use it to walk toward a spring of water. The small farmer argues as well that if he had more money, he would use it to buy his precious corn. Thus, prosperity is not necessary since it is not necessary to change his way of life.

Arcadia is an extremely powerful traditional motif that protects the organic propaganda from possible rational and scientific objections, the latter usually not structured as narratives but of hard to understand concepts. The life of farmers is not jeopardized by poverty, since what the reader considers poverty is actually a harmonic and fulfilling way of life. Actually, it is jeopardize by greedy capitalism and money, which corrupts the purity of the countryside.

The text ends with the "thankyou but no" motif: "Thankyou my friend, as you will see, we keep our corn for many reasons but above all because its value is our life, and that is much greater than money." No money can buy the value of the corn. "You" may think that offering a better technology and more opportunities for profit will be on his favor but that is because you wrongly believe that the small farmer values money over his life. He does not although it may be difficult for "you", who live in the city, to understand.

\section{Value}

The word "valor" (value) appears five times in the text and it is crucial for the message since one of the goals is showing the different meaning of "valor" for the small farmer. The text assumes that the second person considers that "value" equals "money." However, the farmer shows that value has for him a very different perspective. For him, valuable things are his ancestors' legacy, moments of happiness, keeping the recipes and his lifestyle.

Table 3 shows the contexts in which the word is used and what may be lost when money becomes the measure of value:

Table 3. The Word "valor" (value) in "The Small Farmer"

\section{What is lost?}

For me and my family, this corn plant is pride, a treasure and a legacy from my grandparents, who in turn received it from their grandparents hundreds of years

Legacy, pride, inheritance ago. It's a family legacy and that has a very important value for us.

If I take away their food, and give them another, they would cease to be happy and would make us very unhappy. This has a great value.

Happiness

With this corn, we also make all the recipes that we have loved so much since all our lives, our humitas [fresh corn tamales], our corn with cheese, our lawita [corn Recipes soup]. What would we do with that other corn? This is of immense value.

Dear friend, it seems that there in the city the value is only money. Of course we would like to earn more money but much more important for us is to gain moments of happiness, respect and appreciation for our history and our land.

Moments of happiness, respect, appreciation of history and land

Thank you my friend, as you will see, we keep our corn for many reasons but above all because its value is our life, and that is much greater than money. 
"Valor" is an important word since what is at stake is the meaning of value. For the second person, value equals money. However, for the small farmer value is a transcendental and an existential experience that money cannot buy. The main argument of the story is that we cannot assess poverty with urban eyes. The small farmer looks poor, but he is not because he values life in a very different way. Corporate greed would damage the lifestyle he inherited from his ancestors. If he uses GMOS, he may get more money, but he and his family would lose the richness of a fulfilling life. An ancient legacy would be lost and life would be miserable and meaningless.

Interesting enough, the small farmer comes to the realization that his corn has more market value than the transgenic corn: "And finally, we sell the rest of the corn at a price that each day is fairer because, I do not know if you know dear friend: every day, people want more and more our choclito while yours, I have been told, every day they want less." This is a telling contradiction within the discourse since the small farmer is not actually ignorant about how the market value works. He is aware for a moment that the greedy market appreciates his traditional corn over the technological one. Although the "value" of his corn cannot be exchanged with money, if he realizes that it is a commodity.

\section{Conclusions}

Gaston Acurio's "The Small Farmer" is an epitome of the organic propaganda associated with the Peruvian "gastronomic boom." The strength of his argument lies in a narrative woven as a romance between the farmer and the land, both animate beings living harmoniously and from which the beautiful and nutritious fruit emerges. The farmer's work is tiring, but not alienating. This means that there is a continuity between the subject of the work and the object produced, which represents it perfectly. Technology is an interference that not only contaminates the relationship between the subject producer and the food produced, but also violates nature itself and attacks the earth. The text is strongly associated with the pastoral genre and reframes archaic and animistic motifs that refer us to the adoration of natural forces and, in particular, to the earth as a source of production and reproduction. History, in the sense of progress and violence, is on the margins of this portrait that invokes the nostalgia eventually fulfilled by the tasting of the fruit of the earth, in this case, the organic corn. The experience of this type of food serves as a comfort to the routine and alienating life of the city, the one in which the reader and diner are located. "The Small Farmer" is a compelling story as long as it satisfies our fantasies in which peasants' poverty is no longer a social problem but a bucolic and meaningful lifestyle.

We dream on being what we are not. We fantasize with having what we do not have. For centuries, science and technology has been accomplishing ancient dreams like extending life, conquering mortal diseases and flying to the Moon. Yet, science and technology is failing in providing postmodern individuals with satisfactory images. Tales about alienation and meaningless lives are powerful and feed our fantasies. However, they can also bring doubts about our power to control nature. Science communicators must be aware that truth is not enough to influence on popular mindsets. They also need powerful and meaningful narratives.

\section{References}

Bakhtin, M. (1982). The Dialogic Imagination: Four Essays. Austin, USA: University of Texas Press.

Benbrook, C. (2012). Impacts of genetically engineered crops on pesticide use in the U.S. the first sixteen years. Environmental Sciences Europe, 24(1), 1-13.

Bourdieu, P. (1985). The Social Space and the Genesis of Groups. Theory and Society, 14(6), 723-744.

Bourdieu, P. (1986). The forms of capital. In Richardson, J. (Ed.), Handbook of Theory and Research for the Sociology of Education (pp. 248-251). New York, USA: Greenwood Press. 
Bourdieu, P. (1989). Social Space and Symbolic Power. Sociological Theory, 7(1), 14-25.

Brecher, J. (2015). A Strategic Proposal to Stop Climate Change. Labor Forum, 24(2), 18-24.

Bruner, J. (1991). The Narrative Construction of Reality. Critical Inquiry, 18(1), 1-21.

Cook, J. (2019). America Misled: How the fossil fuel industry deliberately misled Americans about climate change. Fairfax, USA: George Mason University.

Dargent, E. and Urteaga, M. (2019). The Power of the Seed:Timing, Quick Structural Change, and Genetically Modified Crop Regulations in the Andes. Comparative Politics, 51(4), 539-561.

Guerrero, D. (2018). The Limits of Capitalist Solutions to the Climate Crisis. In Vishwas, S. (Ed.), Climate Crisis, The: South African and Global Democratic Eco-Socialist Alternatives (pp. 29-46). Johannesburg, South African: Wits University Press.

Gupta, R. and Musunuru, K. (2014). Expanding the genetic editing tool kit: ZFNs, TALENs, and CRISPR-Cas9. The Journal of Clinic Investigation, 124(10), 4154-4161.

Hsu, P.D., Lander, E.S. and Zhang, F. (2014). Development and applications of CRISPRCas9 for genome engineering. Cell, 157(6), 1262-1278.

Jamieson, K.H. (2017). The role of language in expressing the life sciences in a polarized age. Politics and the Life Sciences, 36(1), 47-53.

Klümper, W. and Qaim, M. (2014). A Meta-Analysis of the Impacts of Genetically Modified Crops. PLOS ONE, 9(11), e111629.

Komor, A.C., Badran, A.H. and Liu, D.R. (2017). CRISPR-Based Technologies for the Manipulation of Eukaryotic Genomes. Cell, 168(1-2), 20-36.

Krebs, J.E., Goldstein, E.S. and Kilpatrick, S.T. (2014). Lewin's Genes XI. Burlington, USA: Jones \& Bartlett Learning.
Labov, W. (1982). Speech Actions and Reactions in Personal Narrative. In Tannen, D. (Ed.), Analyzing Discourse: Text and Talk. Washington, USA: Georgetown University Press.

Lakatos, I. (1978). The Methodology of Scientific Research Programmes. Cambridge, England: Cambridge University Press.

Lander, E.S. (2016). The Heroes of CRISPR. Cell, 164(1-2), 18-28.

Ormond, K.E. et al. (2017). Human Germline Genome Editing. The American Journal of Genetics, 101(2), 167-176.

Saik, R. (2019). Food 5.0. Austin, USA: Lioncrest Publishing.

Solli, A., Bach, F. and Akerman, B. (2014). Learning to argue as a biotechnologist: Disprivileging opposition to genetically modified food. Cultural Studies of Science Education, 9(1), 1-23.

Sweeny, S. (2015). Green Capitalism Won't Work. New Labor Forum, 24(2), 12-17.

Taxler, G. (2006). The GMO experience in North and South America. International Journal of Technology and Globalisation, 2(1/2), 46-64.

Westropp, H.W. (1880). Notes on Fetichism. The Journal of the Anthropological Institute of Great Britain and Ireland, 9, 304-311.

.

